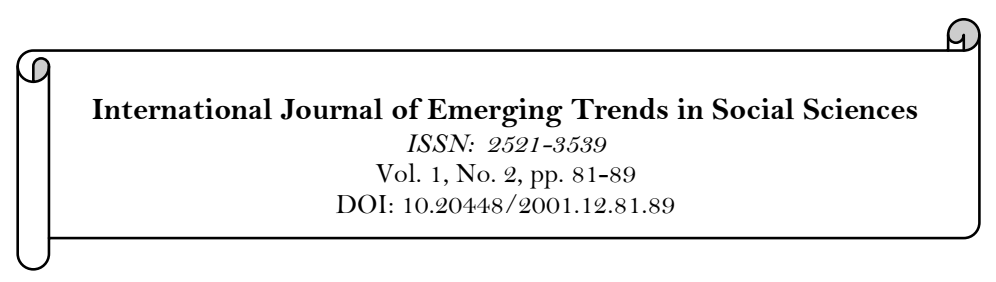

\title{
Mitigating Financial Burden of Elderly through Social Protection Schemes: Issues and Challenges for Pakistan
}

\author{
Hasan Raza ${ }^{1}$ \\ Farooq Ahmed ${ }^{2}$ \\ Zaeema Asrar Mohiuddin ${ }^{3}$ \\ Ahmed Osama ${ }^{4}$ \\ ${ }^{1,3}$ Assistant Professor, Department of Commerce, University of Karachi, Karachi. \\ ${ }^{2}$ Lecturer, Department of Commerce, Federal Urdu University of Arts, Science \& Technology, Karachi. \\ ${ }^{4}$ MPhil Scholar, Department of Commerce, University of Karachi, Karachi.
}

\begin{tabular}{l|l} 
Abstract & \\
The study on social protection programs for elderly in Pakistan & Keywords: \\
indicates an absence of concrete and clear frameworks developed by & Social protection \\
government. Most social security and cash assistance programs for & Retirement plans \\
the elderly are ad hoc arrangements which are made in response to & EOBI \\
circumstantial demands or advocated by international donor & Social security. \\
organizations which usually have their own agenda and priority. & \\
Ageing is the reality of every individual's life therefore it is important & Licensed: \\
to save the social status of elderly people \& ensure a progressive life. & This work is licensed under a \\
It is also observed that there are programs and frameworks but & Creative Commons Attribution \\
contains duplication and overlapping that create hurdles in designing & 4.o License. \\
a comprehensive and purposeful social protection strategy for elderly & \\
in Pakistan. The lack of such initiatives can cause difficulty for & Publisher: \\
elderly people in planning their future. This paper presents a review & Scientific Publishing Institute \\
of available programs offered for elderly in Pakistan in order to & \\
reduce the financial burden and what challenges are faced by them in & \\
accessing information about these programs. The paper also looks at & \\
identifying gaps and suggests a "way forward” for future \\
contribution towards this important yet ignored issue. The paper
\end{tabular}

\section{Introduction}

Today, Social Welfare is more than just charity, generosity of the rich, and temporary and short term relief from problems. Development is now based in the intrinsic value of bringing permanent and tangible change for the lower-income groups of the society, helping them curb their lack of finances, cultural complexity or any social or physiological redundancies. According to Planning Commission Government of Pakistan (2013) Social Welfare in Pakistan is an essential element of national development policies and plans. Ageing population is a recognized global issue, both in the developed and in the developing countries. Life expectancy has been rising due to technological, sociological and biological advancements and has given birth to the concepts of longevity as opposed to shortness. This phenomenon of longevity has become a huge concern for nations around the world.

According to statistics, the number of elderly people would increase from 810 million to quarter more by 2020 and out of every five people; one would be over the age of 60 by the year 2050 i.e. 2 billion older people. 
Table-1. Top Ten Countries with the Highest Population (in Millions).

\begin{tabular}{l|l|l|l|l|l}
\hline$\#$ & Country & $\begin{array}{l}\mathbf{2 0 0 0} \\
\text { Population }\end{array}$ & $\begin{array}{l}\mathbf{2 0 1 0} \\
\text { Population }\end{array}$ & $\begin{array}{l}\text { 2012 } \\
\text { Population }\end{array}$ & $\begin{array}{l}\text { 2050 } \\
\text { Expected Pop. }\end{array}$ \\
\hline 1 & China & 1,268 & 1,330 & 1,343 & 1,303 \\
\hline 2 & India & 1,004 & 1,173 & 1,205 & 1,656 \\
\hline 3 & United States & 282 & 310 & 313 & 439 \\
\hline 4 & Indonesia & 213 & 242 & 248 & 313 \\
\hline 5 & Brazil & 176 & 201 & 193 & 260 \\
\hline 6 & Pakistan & 146 & 184 & 190 & 276 \\
\hline 7 & Nigeria & 123 & 152 & 170 & 264 \\
\hline 8 & Bangladesh & 130 & 156 & 161 & 233 \\
\hline 9 & Russia & 146 & 139 & 142 & 109 \\
\hline 10 & Japan & 126 & 126 & 127 & 93 \\
\hline TOP TEN Countries & 3,618 & 4,016 & 4,096 & 4,950 \\
\hline Rest of the World & 2,466 & 2,829 & 2,921 & 4,306 \\
\hline TOTAL World Population & 6,084 & 6,845 & 7,017 & 9,256 \\
\hline \hline
\end{tabular}

Population explosion is an evident global phenomenon that is another fact of longevity. Looking at researches from different parts of the world, it appears that the old-aged face a high level of neglect and alienation. The situation is worsened as the caregivers remain preoccupied with their own problems. Some of the key concerns with respect elderly population in South Asia are:

- By 2050, 20\% of the population (one in five people) will age 60 or above

- More than 50\% (or half of the elderly women) in South Asia are widowed or own their own

South Asian population is growing faster and older than any other part of the world; Help Age International (2006).

The most vulnerable of the elderly are those who suffer from a lost family, those who lack financial power and those who are handicapped or injured. The elderly also suffers from a lack of easily accessible humanitarian aid. They often are deprived of basic services due to their immobility, social invisibility and the presumption that someone is already catering to their needs.

Older population is categorized as vulnerable population, those exposed to higher chances of being attacked: by prevailing conditions of the society or other groups within societies.

It's a fact more concern has been shown about the early development of human kind and how early childhood development affects the personality of people but, less has been the focus on the last stage of human being that is old age also known as ageing. Ageing is defined by Bowen and Atwood (2004) as, the accumulation of changes in a person over time. Social protection Initiatives (SPIs) are meant to procure income or assets to the poor. Through SPIs, marginalized groups such as the elderly are not only protected against livelihood risks, but also get their rights and improvement in their social status. Purposefully developed administered and targeted SPIs result in higher employment levels and reduced losses of human capital. They also in poverty alleviation as marginalized groups are protected against financial and economic shocks. Thus, effective protection measures are a key component of social policy and results in improvement in social stability.

According to the comparison between statistics of Pakistan's elderly population, there were 2.92 million in 1961 and 7.34 million in 1998. Current figures show an increase of more than 11 million older people in Pakistan in 2013.

\subsection{Objectives of the Study}

This research in the absence of a comprehensive available data about social protection programs for elderly aims to:

1. Explore existing Social Protection Programs with respect to elderly in Pakistan.

2. Find out hurdles faced in formulating a comprehensive social protection programs.

3. Recommending a way forward for devising social protection initiatives to facilitate the elderly of Pakistan.

\subsection{Research Methodology}

The type of research conducted is exploratory as not much information and research is available on this topic in Pakistan.

\subsection{Data Collection Methods}

The collection method for the research is secondary data through "desk research" and "literature review". The analysis and recommendations put forward however are of the author. 


\subsection{Social Protection and Poverty}

Society has many stratums existing within it, and as such it is important to underline the issues these strata face due to changing trends and patterns. Social protection, as articulated and defined by the (United Nations Research Institute for Social Development (UNRISD), 2010) it is the prevention management and control of situations that negatively affect wellbeing of the people.

In today's world, an overwhelming majority of people feel insecure and with the rise of poverty in developing countries, this social dilemma is reaching to greater bounds. Members of the Old Age and Childhood age brackets are highly at risk with this phenomenon and these people are gradually becoming part of a sidelined, helpless and hidden stratum of any population in today's society. They suffer from a fundamental scarcity of basic resources which make up the education system, the health unit and availability of respectable job opportunities. Such hostile levels of poverty are causing a breakdown amongst these people who are forced to live a life which is humiliatingly painful and is at a lack of providing any solace, albeit mental, physical or financial; Kugel and Nazareno (2012). A well-grounded understanding of different trends and priorities in wider development policy making is imperative, in order for opportunities to be potentially exploited. In earlier times, economic progress was considered the main yardstick for measuring development. Nevertheless, new paradigms with different outlooks to the old age stratum have also emerged in the past few years as highlighted below.

\begin{tabular}{|c|c|c|}
\hline Concept & Meaning & Affects \\
\hline $\begin{array}{l}\text { Economic } \\
\text { Development }\end{array}$ & $\begin{array}{l}\text { This encourages changes in structure, } \\
\text { which should foster long-run } \\
\text { economic growth. }\end{array}$ & $\begin{array}{l}\text { To make the elderly understand their own } \\
\text { economic strength and to eliminate or } \\
\text { diminish factors which makes the use of } \\
\text { dependency based policies inevitable. }\end{array}$ \\
\hline $\begin{array}{l}\text { Sustainable } \\
\text { Development }\end{array}$ & $\begin{array}{l}\text { This urges to cater for the present } \\
\text { generations in such a way that the } \\
\text { future generations' life chances are } \\
\text { not compromised; United Nations } \\
\text { Documents (2013). }\end{array}$ & $\begin{array}{l}\text { To guarantee that present developmental } \\
\text { steps do not cause problems for the future in } \\
\text { terms of old age. }\end{array}$ \\
\hline $\begin{array}{l}\text { Human } \\
\text { Development }\end{array}$ & $\begin{array}{l}\text { According to Human Development } \\
\text { Reports, (2012): To create a } \\
\text { constructive surrounding where } \\
\text { people are encouraged to work upon } \\
\text { their skills and live meaningful lives } \\
\text { with relevance to their own } \\
\text { requirements. }\end{array}$ & $\begin{array}{l}\text { To educate and train the elderly so they may } \\
\text { develop and embrace better lifestyles and a } \\
\text { stronger health unit. }\end{array}$ \\
\hline $\begin{array}{l}\text { Poverty } \\
\text { Reduction }\end{array}$ & $\begin{array}{l}\text { To reduce the ratio of poor people } \\
\text { globally as part of the Millennium } \\
\text { Development Goals, which is also an } \\
\text { agenda for agencies such as the } \\
\text { World Bank. }\end{array}$ & $\begin{array}{l}\text { To highlight the reasons and effects of } \\
\text { poverty on older people as part of the } \\
\text { mainstream program. }\end{array}$ \\
\hline
\end{tabular}

Social protection is based on such policies and programs which are intended to effectively diminish this deficiency and irregularity of funds by harbouring effective platforms of job opportunities, bringing the risk level down to a minimum for the elderly, and psychologically and practically preparing them for the financial, health-based, physiological and mental issues which might come their way.

It is imperative for administrations and policy-makers to consider what effects their policies have on the general masses, belonging to all strata and backgrounds. It is important that such policies are devised which work towards equal opportunities in education, work, health, and security of people of every age bracket present, so that this may help them with better life chances as reported by United Nations (2008). Ageing is a common part of every individual's life and although a lot of development has begun to take place in prevention of health issues for this group; less has been done to protect their social status. Social protection guarantees and assures that the needs of the elderly people will be fulfilled through a system presented either by the public sector or private philanthropic institutions around the world.

Social protection policies help the elderly by guiding them towards new directions that ensure a progressive life despite age limitations and improve their quality of life through programs and initiatives designed specifically for this group. The strengthening of relationship between well-being of elderly people and social protection policies significantly depends on information and access to these initiatives. If there is lack of knowledge about such initiatives, it can cause difficulty for elderly people in planning their future.

Help Age International described in their report "Why Social Pensions are needed Now "in 2006 that in developing countries, rise in the number of poor is mainly represented by chronically poor older people. Two 
of the three elderly people in such regions get no regular income; while a 100 million people have just US $\$ 1$ or less for their daily spend.

\subsection{Social Protection and Religion}

Religion has a positive effect in society and plays a significant role in our day to day tasks. Religion gives the framework to follow a good life and avoid the evils of this world through law and guidance on every aspect of life. Be it education, health, science or social welfare. The concept of "Poverty" and inability to fulfil economic needs is not new to mankind but how to fulfil this demand and provide them with social security through welfare systems continues to evolve throughout history. Several attempts have been made for developing a system that would facilitate the needy and deprived.

How should humans behave and what constitutes right and wrong in this world has been mentioned in all the religions of this world. The act of behaving appropriately with other fellow beings is the essence of gaining respect in society and a step forward in reducing conflict and ill will which has led to various wars and genocide globally. Caring for others has been a common thread between all religions and traditions of this world.

The Roman Emperor "Trajan" Hammond (2013) broadened the concept of social welfare to help the poor during his rule, similarly in Jewish tradition; charity makes up part of the religious obligation and contemporary. Ness and Larson (2002) elaborated that Religion has connection with old age it has been searched out in different studies that how church participants had a higher spirituality quotient. These studies have also discussed old age in terms of religious satisfaction and happiness.

In the Islamic Economic system, Alms giving (Zakat) is one of the major principles of the religion, and has been imposed in effect ever since the reign of the second caliphate Umar bin Khattab in the 7 th century. These taxes were utilized for distribution of wealth amongst the poor and the needy which also encircled the elderly, the orphans, the widows and the destitute; Crone (2005). Islam had come at a time when there was a lot of injustice in society and exploitation of wealth was one of the major aspects that led to inequalities amongst the people. The weak in wealth, status and health were dominated by the powerful ultimately resulting in the destruction of society. Islam gave protection that was required at that time to the poor and disabled and helped in gaining a respectful way of life where there was justice irrespective of their age, background, colour or race. This helped in uplifting the lost respect of people including the elderly in that era.

Islam is one of the foremost empires which introduced employment based insurance, which arrived in the Western Europe years later in the 19th century. If an individual became injured or was unable to work and had become redundant, the government was responsible for fulfilling his basic needs by receiving allowance from the treasury; as according to translation of Abu Yusuf Ya'qub, Kitabu'l-Kharaj; interpreted by Shemesh (1969). Hamid (2003) described that during the Caliphate, it was the duty of the state to provide funds for redundant employees by providing allowances from the state treasury. Even pensions were provided to the retirees and those who were no longer eligible to receive salaries or stipends; said by Crone (2005). Keeping the increased levels of poverty and ageing population in context, both national and international stakeholders are debating over the issue of evaluating pension and social security policies. With the arrival of the old age phenomenon, and its rapid growth, administrations and public policy officers are beginning to re-invent their systems to cater for the global change. This aspect is more highlighted in developed countries which have gone through changes in demographics due to rise in the elderly population. However, Mahmood and Nasir (2008) elaborated that developing countries which are still undergoing change in demographics, like Pakistan, are keeping a keen eye of this matter as well, and the affects which ageing would have on not only their current scenario, but also on the future to come.

\section{Issues and Challenges for Pakistan}

\subsection{Public Sector Policies and Services for Older People}

Pakistan, since its origin, has faced problems in managing its demographic balance and little focus is given towards the elderly in Pakistan. There is no policy on national or provincial levels in the country regarding this issue, which causes difficulty in implementing basic rights of the elderly. However, there have been steps taken for the benefit this stratum through various policies and programs in the country such as pension schemes, Employees Old Age Benefit programs, Bait-ul- Maal etc.

The country's economic and social development is one of the main agendas of the Constitution of Pakistan and this constitution furthermore holds the state responsible for catering for the people who are completely or partially at a loss of earning any form of decent income due to physical, psychological or physiological problems. The state is responsible for the wellbeing of such citizens in the country. In Pakistan, problems pertaining to residence, finances, health-based issues and methods of catering for the elderly in a more progressive way have become of vital importance and are continuously being addressed on different government forums. The life expectancy rate in Pakistan has improved over the years because of exceptional breakthroughs in investigative and medicinal methods, improvement in public sector healthcare; schemes launched by the government to effectively mitigate poverty, and increased awareness at the hands of the media. This pattern hints at an increase in life expectancy ratio from 60 years currently to 70 soon. Bronson 
(1949) said that the pension plans are defined as benefit plans financed on "Pay as you Go" and "owe as you go". Public civil servants are eligible to receive pensions on retirement at the age of 60 . People working in business sector are not obliged to retire and can continue to work and receive old age pensions only if, their organization is registered with employees old age benefit institution. Informal sector workers, freelancers and self-employed, agricultural workers do not receive protection from the state at old age or at any emergency. In these situations of emergencies civil society and philanthropist play major role in the welfare of these individuals, mostly poor.

For effectively dealing with these changes and upcoming challenges, many steps have been taken. Few are named: Employees Old Age Benefit Act 1976, Social Security Act: 1965, Pension plans, Government Employees Benevolent Fund, and the proposed Senior Citizen Bill 2009.

\subsection{Pension for Government Employees}

In Pakistan, pensions are largely considered as provisions, usually given to pensioners of the private sector. The private sector is perhaps the only area which benefits from pensions, most social policies cater for a small percentage of the elderly strata. Thus, a larger, more significant cut of this population, belonging to the public sector, remains largely shelter-less by the schemes and plans provided. Ideas to develop and implement reforms in the pension section of Pakistan have been discussed by Mahmood and Nasir (2008) keeping in view that resources are efficiently deployed and the eligible and economically weak portion of this strata also receives and is endowed with this social security rights.

According to International Labor Organization (2010) globally, around 40 per cent of the working age group has legal coverage through elderly-based policies. But still, just a few are catered for. Alongside this, 75 per cent of people above or at 65 in first world countries are receiving of pensions, but in developing countries the group receiving pensions in less than $20 \%$, with a median of about $7 \%$. The average number of individuals turning 60 per year, around the globe, is approximately 58 million. In the last decade, the amount of elderly in 60 s or above have increased to 178 million (the same number as that of the population of Pakistan). And the number of elderly people last year was 180 million in China alone; as reported by United Nations Population Fund and Help Age International (2012).

Pakistan faces a multitude of challenges. Due to lesser finance allowance in the sectors of education and medicine is taking place, which in turn affects the underprivileged and elderly dependent families with more harshness and hinders their access to social services. The elderly has faced difficulty in accessing to facilities due to many gaps in programs for this stratum in Pakistan but few initiatives have been taken by the government.

\subsubsection{Government Employees Benevolent Fund}

The Federal Employees Benevolent \& Group Insurance Fund (2013) after being inaugurated in 1969, became largely handled by a board of trustees who would overlook the matters of all government and other related organizations' employees and their pension funds. Accordingly, the seven forms of benefits which are provided to the members of this fund include the Monthly Benevolent Grant, Sum Assured, Marriage Grants, Education Stipends, Burial Charges, Farewell Grants and Lump Sum Grants. Approximately 40\% of households have benefitted from this fund and more than 580,000 state employees are part of these schemes as well; FEBGIF, Government of Pakistan (2013).

\subsubsection{Social Security Scheme in Pakistan}

Pakistan faced the emergence of social security schemes in 1967, when the West Pakistan Employees' Social Security Ordinance No. X of 1965 was established. Every province runs its own social security scheme under the same ordinance. The Sindh Employees' Social Security Institution (SESSI) became established in 1970 , as the plan was spread across all the provinces. The main purpose of this scheme was to cater for the workers in Karachi and Hyderabad cities in the textile industry, but after becoming popular enough, the scheme broadened its horizons towards other commercial industries and businesses as well leaving agricultural sector unattended. All other three provinces have their social security welfare institutions like Sindh.

\subsection{Functions}

The primary functions of the SESSI is to overlook the medical and financial care being provided to permanent employees and their family members with regards to any unforeseen circumstances in which the individual might find himself.

\subsection{Governing Body Function}

The governing body must deal with:

- Budget estimates approval, as well auditing of accounts and preparation of annual reports.

- Furtherance of the objects of the Ordinance. 


\subsection{Directorates Function}

The functions of directorates are to collect contributions, cash payments, register employees, and overview the upcoming projects.

Medical Circles Function

Provision of medical care and relevant facilities to permanent workers and their family members is very significant also.

\subsection{Hospitals Function}

Hospitals are to provide specialists medical care to permanent workers and their families through OPD and IPD. Further, laboratory tests, X-ray, ultrasound, dialysis, endoscopy, etc. are performed; (Sindh Employees' Social Security Institution, 2013).

\subsection{Employee's old Age Benefit Scheme}

The scheme was at first, exclusively used for the private sector employees to make sure that they receive the right to have pensions once they retire. This was done in 1976, and according to the scheme, any company or industry or factory owning 5 or more workers was entitled to providing them with the basic earnings-based pension program.

\subsection{Criteria for Selection}

The ideal pension age for earning-based pensions is considered to be 60 and 55 for males and females respectively; however, 15 years of work experience is required for females. For government pensions, but men and women have the same retirement age i.e. 60. The criterion is different for civil servants.

\subsection{Benefit Calculation}

Pensions, generally tied to an individual's income, are calculated as $2 \%$ of the average monthly earnings multiplied by years of service. The rule of indexation in pension payments stands discretionary hence the model presupposes price-indexation.

\subsection{Minimum Pension}

The pension rate at the lower bend, in 2010, was Rs. 3000/month. Again, the rule of indexation for pension payments is discretionary but the pension amount for both maximum and minimum insured earning is Rs. 6,000 a month. The private formal sector receives its pension coverage through the Employees Old Age Benefits Institutions (EOBI) that is maintained by the state and the Employees' Pension and Social Security Institutions (ESSI), which is at the provincial level. These covers only a limited 2.15 million employees and their family members included.

Table-3. Number of Households Covered Under Various Social Assistance.

\begin{tabular}{l|l}
\hline Programs & Number of Household covered \\
\hline Employees Old Age Benefit Institutions & 1.30 million \\
\hline Employees Social Security Institutions (Mostly covered by EOBI) & 0.85 million \\
\hline Zakat & 1.70 million \\
\hline Bait-ul-Mal Financial Assistance & 0.02 million \\
\hline Bait-ul-Mal Food Support Program & 1.25 million \\
\hline Source: Employees Old Age Benefit Institutions. &
\end{tabular}

An ageing population is the result of interconnected development gains. A population will have more of the elderly not only because of improvements in healthcare, but also because of other contributing factors like improved nutrition, better hygiene, literacy and income. At the same time, however, ageing poses a stream of challenges for individuals, households and the society at large.

According to United Nations Population Fund, ageing is the most important population issue for the present century. About $10 \%$ of the world population (one in 10 people) is aged 60 or above, which by 2050 is predicted to rise to $20 \%$, or one in 10 people. This structural shift in population is going to have wide implications, especially for countries in the developing world. Although ageing is a central issue for all countries, it is likely to affect populations of the developing countries, which generally have larger share of young people.

Seven of the fifteen countries having 10 million or more elderly people are developing countries, which include highly populated countries like Pakistan. Currently, Pakistan has about 11.6 million (6.5\% of the population) aged 60 or above. The forecasts state that Pakistan will have over 43 million $(15.8 \%$ of its total population) people aged 60 or more by 2050. The inevitability of the forecasted demographic structure calls upon policymakers to adequately and effectively develop health and social security policies specifically aimed for the elderly. If not, changes in demographics will excessively burden families and caregivers of the elderly, especially those who struggle to meet their ends. A high amount of effort is also desired in addressing the 
health issues of the ageing strata of the population. There is a need to make addition and improvements in the public healthcare facilities meant for the elderly. Development of health insurance schemes for the aged can also be of great relevance and efficacy.

Increasing the investments in the pension systems can greatly reduce economic dependence and poverty in the old age. Apart from people who retired from government or well-to-do firms, employees (especially in developing countries) generally cannot expect much support as soon as they cease to work.

Decades ago, Pakistan established an Employees' Old-Age Benefit Institution (EOBI) to cater for financial needs of the retired employees. Through the EOBI Act of 1976, the government directed all employers to provide mandatory social insurance benefits to their workers. The EOBI scheme did not provide for financial support from the government, it directed that the employers allocate five per cent and employees one percent of the minimum wages from their salaries to assure EOBI benefits at the time of retirement. Ten years ago, the coverage of EOBI schemes catered to only five percent of the entire labour force. The situation perhaps remains unchanged as employers keep neglecting EOBI directives altogether or officially declare large part of their workforce as contractual staff. The informal sectors comprising of agro-businesses, cottage industries and the like also do not subscribe to EOBI schemes.

Ali (2012) said that the government needs to reprioritize the policies intended towards the ageing population. In addition to investments in the health and safety programs, the government needs to introduce measures that push employers to provide adequate pension coverage for their employees. Without so doing, Pakistan cannot offer much comfort for the elderly.

Being old-aged citizen is a challenge in Pakistan. In addition to several deprivations, the elderly face alienation both from their families and the society. They are the most vulnerable to economic shocks and hence are most marginalized, leading them to spend stressful lives. Large numbers of elderly are compelled to continue work till death. They remain underpaid and are subject to irregular and unsafe working conditions. It is unfortunate that even political, religious and social organizations have little or nothing in their manifestoes regarding their approach for the betterment of the elderly as reported by Habib (2011).

\subsection{Private Sector Policies and Services for Older People in Pakistan}

Joint family system is dismantling due to urbanization and modernization due to which support system have become weaker especially for poor that includes elderly poor. Simultaneously, Provisions of social transfers are becoming a challenge in terms of pension, health care and social protection. Immediate reforms and their fastest execution are inevitable for public policy to avoid disorganization in society. At the moment, only the formal sector employees have the provision of regular pensions. While several social protection schemes have been introduced in the public and private sectors, only a handful is meant for old-age population.

Similarly, the private enterprises through their corporate social responsibility programs have started to highlight social issues for creating awareness amongst masses through various campaigns. The scenario in Pakistan is however comparatively very new and only a few organizations have a CSR policy in place but with no income support programs or any other initiative aiming at elderly population. The development sector in Pakistan like other countries is also growing and expanding to facilitate the needs of deprived people through various programs and initiatives. Non-Government Organisations (NGOs), both local and international are playing a significant role in rural development, policy advocacy, environment, family planning, human rights and other developmental issues in Pakistan. In order to share the burden with the Government in development programs, the role of voluntary Organizations/private welfare organizations are emerging as an important social service provider for communities in the various areas of society including the issues of elderly in Pakistan. Some contributions by private sector organizations are discussed below:

\subsection{Help Age International}

Help Age International provides serves the elderly by helping them claim financial rights, confront discriminatory treatment and rise above poverty to spend a secure, active, healthy and dignified life. Over 100 organizations in 65 countries are affiliated to Help Age International.

Help age International entered Pakistan during the floods of 2010 with the desire to stay. HAI intended to bring socio-economic prosperity within displaced, rural poor and specifically older communities through combining sustainable livelihood and participatory approaches. Simultaneously, HAI is also propagating its mission statement of challenging discrimination and overcoming poverty within older people through this program. Provisions of Continuous Revolving Funds (CRF) to older poor are an exceptional practice especially of income support in Pakistan. Age specific policies at work and societal norm have excluded fit and active older people from working and receiving loans for several purposes here in Pakistan. In this situation introducing Community Revolving Fund (CRF) by HAI has broken the ground for innovative development designs. This program is specifically designed to provide opportunities to older men and women to standout of their miseries through participating in developing livelihoods for rebuilding in a flood affected area. Provision of microcredit to alleviate poverty for various socio-economic needs is famous and reliable practice in the development sector and is indeed a good fit in this emergency. HAI introduced Older People Association (OPA) within this community and provided them training on disaster risk reduction programs, 
project management skills and awareness about various livelihood options to these older people who were unaware of these areas before.

Many autonomous and semi-autonomous organizations as well as provincial and federal administrative bodies are responsible for development, monitoring and execution of above-mentioned social protection initiatives or social protection schemes, but in the absence of a cohesive and well-targeted social protection policy, such schemes and programs largely operate on an ad-hoc, reactionary and fragmented basis.

In this section, a brief evaluation of the existing social protection programs is made keeping in view their inefficiencies, gaps, flaws and bottlenecks. Empirical research focusing on social protection programs of Pakistan present the following themes:

- There is a lack of coordination among the executive bodies

- Many schemes have inherent design and development faults

- Corruption and inappropriate use of the funds

- Lack of funds or inadequate financial assistance

- Poor or low coverage

- Burdening costs of administration

- Programs frequently overlap or duplicate

- Improper targeting mechanism

- Bureaucratic malpractices and political interferences

- Inadequate monitoring, supervision and control

- Lack of involvement of elderly in key decisions or policy formulation

\section{Recommendations for Future Strategy}

The social protection for Elderly population in Pakistan can be categorized into three groups namely (i) policy process, (ii) design and delivery and (iii) financing.

\subsection{Policy Process}

- There is a definite requirement of policymaking and research on social protection issues. This can be effectively fulfilled through establishment of research centres (centres of excellence) within a couple of current tertiary organizations. Also, involve elderly in devising policies so that the policy is not prepared in isolation.

- All existing national plans for social protection need a review so that their level of efficiency and implementation can be gauged and gaps, if any, be identified and corrected through policy revisions

- To extend social protection benefits to the informal sector, priority must be set for services which workers want the most or will make significant contributions in. This entails provision of microinsurance and social health insurance to ward off interruptions in workers' incomes or earnings.

- Effective and productive safety nets must be developed to support people fight poverty and risk through income support services, with a particular emphasis on cash transfer programs linked to human development outcomes.

- Only 5\%-person benefit from EOBI so it needs to be scaled up by involving the private sector through their corporate social responsibility (CSR) agenda.

\subsection{Design and Delivery}

- There is a need to extend the coverage of social protection programs especially meant for the elderly, such as workers belonging to marginalized groups or workers engaged in the informal sector.

- Issues such as stumbling blocks in obtaining EOBI coverage, inadequacy of funds and bureaucratic malpractices hindering pension support schemes must be addressed.

- Transparency and eligibility criteria of social support programs can vastly benefit from community engagement in fund disbursement. Better evaluation systems and internal controls backed by third party validation can also benefit such programs.

- Existing programs and new initiatives should be regularly evaluated for improving services offered Financing

- The government needs to allocate higher cash provisions for the disabled and the elderly who at present are the most vulnerable groups affected by poverty

- Guaranteed social protection can be provided via public-private partnerships i.e. through combined operations of the government and the development sector institutions.

- CSR funds from various organizations should be used for designing social protection programs for elderly. 


\section{References}

Ali, S. M. (2012). Pakistan's ageing population, express tribune, 11 November 2012. Retrieved from http://tribune.com.pk/story/464108/pakistans-aging-population/.

Bowen, R. L., \& Atwood, C. S. (2004). Living and dying for sex. Gerontology, 50(5), $265-290$.

Bronson, D. C. (1949). Pensions-1949. Transactions of Society of Actuaries, 1(1), 251.

Crone, P. (2005). Medieval Islamic political thought (pp. 308-319). Edinburgh: Edinburgh University Press.

Federal Employees Benevolent \& Group Insurance Fund. (2013). Government of Pakistan. Retrieved from http://www.febgif.gov.pk/Default.aspx.

Habib, Y. (2011). No place of elderly in today's society, Pakistan today, 1st October 2011. Retrieved from http://www.pakistantoday.com.pk.

Hamid, S. (2003). An Islamic alternative? equality, redistributive justice, and the welfare state in the caliphate of Umar. Renaissance: Monthly Islamic Journal, 13(8).

Hammond, M. (2013). TRAJAN, Britanica. Retrieved from http://www.britannica.com/EBchecked/topic/602150/Trajan. Help Age International. (2006). Where we work in South Asia, London, $1 . \quad$ Retrieved from http://www.helpage.org/where-we-work/south-asia/.

International Labor Organization. (2010). World social security report 2010/11: Providing coverage in times of crisis and beyond, Geneva, 2.

Kugel, A., \& Nazareno, J. (2012). Social protection - an effective tool to fight inter-generational poverty, global action on aging February. Retrieved from http://www.globalaging.org/agingwatch/events/CSD/mipaa+5.htm.

Mahmood, N., \& Nasir, Z. M. (2008). Pension and social security schemes in Pakistan: Some policy options (Vol. 1). Islamabad: Pakistan Institute of Development Economics.

Ness, P. H. V., \& Larson, D. B. (2002). Religion, senescence, and mental health: The end of life is not the end of hope. The American Journal of Geriatric Psychiatry, 10(4), 386-399.

Planning Commission Government of Pakistan, S. W. (2013). 8th Plan. Retrieved from www.pc.gov.pk/five\%20year\%20plans/8th/Social\%20Welfare.pdf.

Shemesh, A. B. (1969). Abu Yusuf Ya‘qub, Kitabu'l-Kharaj, trans. London: Luzac.

Sindh Employees' Social Security Institution. (2013). Government of Sindh, Pakistan. Retrieved from http://www.sessi.gov.pk/functions.htm.

United Nations. (2008). Guide to the national implementation of madrid international plan of action on ageing. New York.

United Nations Population Fund and Help Age International. (2012). Ageing in the Twenty-First Century: A celebration and a challenge (Vol. 2). New York and London.

United Nations Research Institute for Social Development (UNRISD). (2010). Combating poverty and inequality: Structural change, social policy and politics (Vol. 13). New York. 